\title{
Cross-examining candidate genes implicated in multiple system atrophy
}

\author{
Jared S. Katzeff, Katherine Phan, Sivaraman Purushothuman, Glenda M. Halliday and Woojin Scott Kim *iD
}

\begin{abstract}
Multiple system atrophy (MSA) is a devastating neurodegenerative disease characterized by the clinical triad of parkinsonism, cerebellar ataxia and autonomic failure, impacting on striatonigral, olivopontocerebellar and autonomic systems. At early stage of the disease, the clinical symptoms of MSA can overlap with those of Parkinson's disease (PD). The key pathological hallmark of MSA is the presence of glial cytoplasmic inclusions (GCI) in oligodendrocytes. GCl comprise insoluble proteinaceous filaments composed chiefly of a-synuclein aggregates, and therefore MSA is regarded as an a-synucleinopathy along with PD and dementia with Lewy bodies. The etiology of MSA is unknown, and the pathogenesis of MSA is still largely speculative. Much data suggests that MSA is a sporadic disease, although some emerging evidence suggests rare genetic variants increase susceptibility. Currently, there is no general consensus on the susceptibility genes as there have been differences due to geographical distribution or ethnicity. Furthermore, many of the reported studies have been conducted on patients that were only clinically diagnosed without pathological verification. The purpose of this review is to bring together available evidence to cross-examine the susceptibility genes and genetic pathomechanisms implicated in MSA. We explore the possible involvement of the SNCA, COQ2, MAPT, GBA1, LRRK2 and C9orf72 genes in MSA pathogenesis, highlight the under-explored areas of MSA genetics, and discuss future directions of research in MSA.
\end{abstract}

Keywords: Multiple system atrophy, a-Synuclein, COQ2, Susceptibility genes, GWAS, Parkinson's disease

\section{Introduction}

Multiple system atrophy (MSA) is a fatal neurodegenerative disease that is characterized by progressive autonomic failure, parkinsonism and cerebellar ataxia [23]. It is an adult onset disease with a mean onset age of $52-59$ years old and an average survival time of 7-9 years from diagnosis $[56,71]$. The annual incidence in the age group 50-99 years has been estimated at 3-4 cases per 100,000 person years $[10,70]$. There are two main subtypes of MSA - a parkinsonian subtype (MSA-P) with striatonigral degeneration and a cerebellar subtype (MSA-C) with olivopontocerebellar degeneration [34, 74]. In Caucasian populations MSA-P cases generally outnumber MSA-C cases by 2 : 1-4:1, however, in Japan MSA-C predominate over MSA$\mathrm{P}[40,41,83]$.

The major pathological hallmark of MSA is the presence of glial cytoplasmic inclusions (GCI) in oligodendrocytes $[50,57]$. The major constituent of GCI is $\alpha$-synuclein, and

\footnotetext{
* Correspondence: woojin.kim@sydney.edu.au

Brain and Mind Centre \& Central Clinical School, The University of Sydney, Sydney, NSW, Australia
}

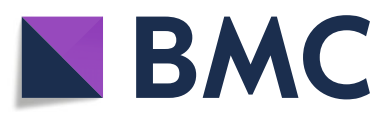

(c) The Author(s). 2019 Open Access This article is distributed under the terms of the Creative Commons Attribution 4.0 International License (http://creativecommons.org/licenses/by/4.0/), which permits unrestricted use, distribution, and

reproduction in any medium, provided you give appropriate credit to the original author(s) and the source, provide a link to the Creative Commons license, and indicate if changes were made. The Creative Commons Public Domain Dedication waiver (http://creativecommons.org/publicdomain/zero/1.0/) applies to the data made available in this article, unless otherwise stated. group of neurodegenerative diseases that also includes Parkinson's disease (PD) and dementia with Lewy bodies (DLB) $[5,26,81]$. Apart from GCI, other cellular inclusions are present in MSA brain, including neuronal cytoplasmic inclusions, neuronal nuclear inclusions and less commonly glial nuclear inclusions $[37,57]$. Although the molecular mechanisms of misfolding, fibrillation and aggregation of $\alpha$-synuclein partly overlap with other $\alpha$-synucleinopathies, the pathological pathway of MSA is unique in that the initial principal site for $\alpha$-synuclein deposition is in the oligodendrocytes rather than neurons; $\alpha$-synuclein is normally concentrated in nerve terminals. It appears that $\mathrm{p} 25 \alpha$, which is required for microtubule stability in oligodendrocytes, plays a role in the $\alpha$ synuclein deposition [30, 52].

Currently, MSA is considered a sporadic disease as no causative genes have been identified, although a number of gene variants has been shown to be associated with increased risk of MSA. In one study, it was estimated that the heritability among common variants to be 
2.09-6.65\% [22]. In a few studies, certain susceptibility genes have been suggested to be familial, including SNCA and COQ2 [2, 46]. Also, the ethnic variation in MSA subtype indicates there may be a genetic predisposition to the specific subtypes of MSA [53]. The purpose of this review is to bring together available data to canvass the genetics of MSA. We will discuss the genes that are potentially associated with MSA - SNCA, COQ2, MAPT, GBA1, LRRK2 and C9orf72 - and recent findings from the MSA GWAS study [65].

\section{SNCA - a-Synuclein}

The relevance of $\alpha$-synuclein in MSA pathogenesis is of considerable focus [86]. $\alpha$-Synuclein is encoded by the SNCA gene located on 4q22.1 [14]. It is concentrated at presynaptic terminals of neurons, where it is postulated to facilitate synaptic activity $[14,17,59]$. In MSA, however, $\alpha$-synuclein is present in aggregated form as a major component of GCI in oligodendrocytes. Aggregation of $\alpha$-synuclein appears to cause decreases in the level of neurotrophic factors in oligodendrocytes, reducing the ability of oligodendrocytes to provide axonal stability [79]. It also appears to impact on the ability of oligodendrocytes to regenerate and repair [88].

Mutations in SNCA (A30P, E46K, H50Q, G51D and A53T) are known to cause PD [4, 38, 42, 61, 91]. However, no causal SNCA mutations for MSA have been found to date, and the association between variant $\alpha$ synuclein and MSA is still unproven. Several studies have investigated the inheritance of SNCA variants in families with MSA $[38,39,58]$. A study of a British family with the SNCA G51D variant revealed neuropathological hallmarks of both MSA and PD [38]. Similar hallmarks were present in two other cases with the same variant [39]. These findings suggest that G51D could be relevant to MSA as well as PD, although it has not been found in cases with only MSA pathology. Similarly, a Finnish family with SNCA A53E variant showed neuropathological hallmarks of both MSA and PD [58]. It should be noted that deposition of $\alpha$-synuclein in oligodendroglia occurs with greater disease severity and duration in PD [28], suggesting that these mutations may be more aggressive PD mutations rather than relevant for the initiation of MSA. At this stage we cannot rule out the possibility of coexistence of the two diseases. Hence, at this stage, it is difficult to conclude if there is a causal link between $S N C A$ and MSA.

The association of SNCA single nucleotide polymorphisms (SNPs) to MSA has also been studied. Two SNPs, rs3857059 and rs11931074, were found to be significantly associated with increased risk of MSA in an European population [67]. A further two SNPs, rs3822086 and rs3775444, were found to be significantly associated with increased risk of MSA in a different
European population [2]. Interestingly, the latter study also found that rs3822086 was significantly associated with MSA-C [2]. In contrast, rs3822086 and rs3775444 were not significantly associated with MSA in a Chinese population[15].

Overall, while current evidence suggests that specific SNCA SNPs are associated with increased risk of MSA in certain populations, no evidence exists for a causal relationship between SNCA and MSA, albeit PD/MSA or MSA-like pathology.

\section{COQ2 - coenzyme Q2 polyprenyltransferase}

COQ2 encodes the enzyme coenzyme-Q2polyprenyltransferase in the biosynthetic pathway of coenzyme $\mathrm{Q}_{10}$. Coenzyme $\mathrm{Q}_{10}$ is an integral part of the mitochondrial electron transport chain; it transfers electrons from complex I and II to complex III [21]. Deficiencies in coenzyme $\mathrm{Q}_{10}$ cause mitochondrial dysfunction, oxidative stress and reduced ATP synthesis [62]. Polymorphisms in COQ2 have been associated with MSA in several studies. In one study, functionally-impaired COQ2 V393A variant was shown to be associated with sporadic MSA in a Japanese population [46]. This association was supported by a meta-analysis in a subsequent study, in which V393A was shown to be associated with increased risk of MSA in Han Chinese, Japanese and possibly broader East Asian populations [93]. In contrast, another study showed that V393A was not associated with MSA in 133 Japanese MSA patients [77]. Likewise, V393A was not associated with MSA in Korean MSA patients [35]. Apart from V393A, other COQ2 variants (e.g. L25 V, M128 V, R173H, L402F, $\mathrm{A} 32 \mathrm{~A}$ and N386I) have been identified in various populations $[16,46,77,85]$. The pathological link between COQ2 and MSA was strengthened when it was discovered that plasma coenzyme $\mathrm{Q}_{10}$ levels were lower in MSA patients compared to healthy controls [48]. Furthermore, coenzyme $\mathrm{Q}_{10}$ levels were found to be lower in the cerebellum, along with increases in mitochondrial dysfunction and oxidative stress, in MSA cases compared to controls [7]. Interestingly, these changes occurred in MSA cases in the absence of any COQ2 variants associated with MSA [7]. Overall, current evidence cannot fully exclude that specific COQ2 variants are associated with MSA in only certain populations or ethnic groups, but that this pathway may be vulnerable to MSA. Further research is required to determine how COQ2 may contribute to MSA pathogenesis and to reconcile the differences in different ethnic groups.

\section{MAPT - microtubule associated protein tau}

$M A P T$ is located on chromosome $17 \mathrm{q} 21.31$ and encodes the protein tau [9]. The role of tau in microtubule assembly and stability has long been established [84]. When phosphorylated, tau forms aggregates and detaches from the microtubules causing microtubule 
instability and degradation $[9,36]$. Tau has been implicated in numerous neurodegenerative diseases including Alzheimer's disease (AD), frontotemporal dementia (FTD), corticobasal degeneration (CBD), progressive supranuclear palsy (PSP), Pick's disease (PiD) and DLB, all of which are considered as either primary or secondary tauopathies $[25,82]$. There is some evidence that tau could be involved in MSA pathogenesis. Although tau is present in GCI [12], it is unclear whether this is due to tau playing an active role in MSA pathogenesis or whether this occurs downstream in the disease process.

Two haplotypes have been identified for MAPT. The $\mathrm{H} 1$ haplotype is associated with increased risk of PSP, CBD and PD [6, 18, 90], whereas the $\mathrm{H} 2$ haplotype rs870723-G allele is associated with decreased risk of late-onset $\mathrm{AD}$ [3]. The MAPT haplotypes also appear to be associated with MSA risk. In a study consisting of 61 pathologically-confirmed cases of MSA, the H1 haplotype was shown to be a risk factor for MSA [80]. In another study consisting of 127 pathologically-confirmed cases of MSA, H2 and H1E were associated with decreased risk of MSA, whereas H1x and H1J were associated with increased risk of MSA [44]. There are six isoforms of tau that exist in the human brain, and different isoforms have been shown to have different pathological effects. Increased levels of the $4 \mathrm{R}$ isoform have been implicated in FTD $[9,11]$, whereas the $3 R$ isoform has shown to be pathologically important in PiD, and both $3 \mathrm{R}$ and $4 \mathrm{R}$ deposit in $\mathrm{AD}$ [82]. Currently, the role of tau isoforms in MSA is unknown.

\section{GBA1 - beta-glucocerebrosidase}

GBA1 encodes beta-glucocerebrosidase, which is an enzyme that cleaves glucocerebroside in lysosomes. Mutations in GBA1 cause accumulation of glucocerebroside in cells and certain tissues, and can cause Gaucher's disease (GD) [1]. GBA1 mutations are also a common risk factor for PD and DLB $[8,92]$. There is some evidence that $G B A 1$ could also be linked to MSA. Sequencing of coding regions and flanking splice sites of the GBA1 gene in 969 MSA patients, sub-divided into Japanese, European and North American cohorts, revealed that the carrier frequency of GD-linked mutations in MSA was $1.75 \%$ across all groups [47]. Interestingly, there was a significant association between GBA1 mutations and MSA-C [47]. In another study consisting of 17 pathologically-confirmed MSA and $82 \mathrm{AD}$ cases, GBA1 mutations - N370S, T369 M and R496 - were present in 4. MSA cases [73]. Importantly, the MSA group had a higher frequency of GBA1 mutations compared to the AD group. However, in a study consisting of 108 pathologically-confirmed MSA cases, GBA1 mutations were not associated with MSA [72]. And, the GBA1 L444P mutation was not associated with MSA in 54
Chinese MSA patients [75]. Furthermore, no association was found with 54 lysosomal storage disorder genes in 375 MSA patients analyzed [60]. With these conflicting findings, there is still much uncertainty over whether GBA1 is linked to MSA.

\section{LRRK2 - leucine-rich repeat kinase 2}

$L R R K 2$ encodes an enzyme that functions as both a kinase and a GTPase in various cellular processes [33]. $L R R K 2$ variants are associated with increased risk of $\mathrm{PD}$ [55, 96]. LRRK2 G2019S is the most common mutation and accounts for $3-10 \%$ of familial PD and $1-8 \%$ of sporadic PD in European populations [32]. LRRK2 mutations, particularly G2019S, have been investigated in MSA, however, to date, no evidence of a causal link between LRRK2 mutations and MSA has been found [54]. Furthermore, no associations were found between other LRRK2 variants (R1628P and G2385R) and MSA in 318 MSA patients of Han Chinese origin [89]. However, a study consisting of 177 pathologically-confirmed MSA cases from American and British cohorts revealed that M2397 T was a protective haplotype for MSA [31]. In a very recent study, the G2019S LRRK2 mutation was found in a neuropathology-confirmed MSA case [64]. Much more research is required to determine whether LRRK2 is linked to MSA.

\section{C9orf72 - chromosome 9 open reading frame}

Expansion of GGGGCC repeat sequence in the C9orf72 gene has been implicated in both amyotrophic lateral sclerosis and FTD [20, 63]. C9orf72 has been investigated in MSA, however no association, as yet, has been found between C9orf72 and MSA. In a cohort of 100 British and American pathologically-confirmed MSA cases, there was no association between C9orf72 expansion and MSA [68]. This finding was verified in subsequent studies of Chinese MSA cases [13, 76], European and American MSA cases [69]. Based on current evidence, it appears that C9orf72 is not linked to MSA.

\section{Other MSA susceptibility genes}

A number of other genes has been investigated in MSA, all of which have not been substantially verified. One of the genes examined is $C H C H D 2$, which encodes coiledcoil-helix-coiled-coil-helix domain containing 2 protein that is involved in mitochondrial metabolism. CHCHD2 V66 M mutation was identified in a MSA patient of Italian heritage [51]. The function of this mutation is unknown. In another study consisting of 89 Chinese MSA patients, it was shown that no $\mathrm{CHCHD} 2$ variants were found and there were no associations between $\mathrm{CHCHD} 2$ and MSA [87]. Two recent studies examined the CAG repeat expansion length of spinal cerebellar ataxia $(S C A)$ genes in MSA. In one, it was reported that the SCA1 
CAG expansions were more common in MSA-C compared to MSA-P or controls in an Italian cohort [49]. In another, it was reported that there were no association between SCA1 CAG expansion and MSA in Chinese MSA patients, rather ataxin-2 (ATXN2) was suggested as a risk factor for MSA [95]. The rs1799964 SNP in tumor necrosis factor- $\alpha(T N F-\alpha)$ and the rs16944 SNP in interleukin1 $\beta$ $(I L 1 \beta)$ have also been suggested to be potential risk factors for MSA in Han Chinese population [94].

\section{Genome wide association study in MSA}

In 2016, a genome-wide associated study (GWAS) comprising 918 MSA cases and 3,864 controls of European ancestry was carried out [65], which is the largest genetic study into MSA to date. No genes were found to be significantly associated $\left(p<5 \times 10^{-8}\right)$ with MSA after stringent multiple corrections. However, there were four genes with a $p$ value $<1 \times 10^{-6}$; these were F-box protein other 47 (FBXO47), elongation of very long-chain fatty acid 7 (ELOVL7), endothelin-1 (EDN1) and MAPT [65]. $M A P T$ was the only gene that has been previously implicated in MSA. Neither SNCA nor COQ2 was found to be significantly associated with MSA. These results suggest that genes other than those previously associated with neurodegeneration could be involved in MSA. The SNPs identified from the GWAS were tested in another study consisting of 906 MSA cases and 941 controls of Chinese origin, however no significant association was found between these SNPs and MSA [27], once again indicating potential ethnic differences in MSA genetics. It is important to note that in both of these two studies, not all of the MSA cases analyzed were pathologically confirmed.

\section{Copy number variation in MSA}

Copy number variations (CNVs) are DNA structural rearrangements, such as deletions, duplications, inversions and translocations, all of which can affect gene dosage [45]. The role of CNVs in the pathomechanisms of AD [19] and PD [43, 78] have been extensively studied. The first indication of a link between CNVs and MSA came from a Japanese study, in which it was reported that $32 \%$ of MSA patients examined were heterozygous for deletions in the Src homology 2 domain containingtransforming protein 2 (SHC2) gene, suggesting that SHC2 copy number is important in MSA [66]. In contrast, however, it was found that changes in SHC2 copy number were insignificant in a group of American MSA patients [24]. A recent study of genome-wide CNV in a Japanese cohort identified $311 \mathrm{CNVs}$ related to MSA, of which three were significantly different in MSA compared to controls [29]. These CNVs were located on CTD small phosphatase-like (CTDSPL), polypeptide $N$-acetlgalactosaminyltransferase-like 6 (GALNTL6) and small nuclear ribonucleoprotein polypeptide $\mathrm{N}(S N R P N)$. Interestingly, all of these CNVs were located in introns, suggesting that the control of expression of these genes is at the level of transcription.

\section{Conclusion and future directions}

In this review, we have cross-examined the genes and genetic mechanisms that are possibly linked/implicated in MSA. It is clear from this and other reviews that the genetic etiology of MSA is poorly understood, and there is no general consensus on genes that increase the susceptibility to MSA. This is due to a few recurring technical issues. Firstly, in most studies the sample size was relatively small with inadequate statistical power to see common gene variants with small effect sizes. Secondly, much of the genetic findings were dependent on ethnicity or geographical regions, suggesting a variety of more recent influences causing MSA associated gene variants. Thirdly, only some studies were carried out on pathologically-confirmed cases of MSA knowing that clinical diagnosis is still poor. Fourthly, associations with different progressions/treatments may have influenced results as only a single time point (i.e. end stage) in the disease has been investigated. Many of these issues have been borne from the fact that MSA is a rare disease and the difficulty in recruiting brain donors, especially in Asian countries. Much research is required to properly understand how the susceptibility genes are involved in MSA pathogenesis and progression, or whether they are involved at all. A larger GWAS comparing Caucasian and Asian cohorts that are pathologically confirmed is required to accurately determine genes that are ethnicity specific. Under-explored areas of MSA genetics include genome-wide CNV screening, gene isoform differences, and the role of different gene haplotypes. Future studies should also include, not only the genes that are normally linked to neurodegeneration, but genes in other pathological pathways, particularly those involved in oligodendroglial function and in mitochondrial dysfunction.

\section{Acknowledgements \\ This work was supported by a grant from The Multiple System Atrophy Coalition. G.M.H. is a Senior Principal Research Fellow of the National Health and Medical Research Council of Australia (NHMRC). S.P. is a NHMRC - Australia Research Council Dementia Research Development Fellow.}

\section{Authors' contributions \\ All authors contributed to the writing of the manuscript. All authors read and approved the final manuscript.}

Competing interests

The authors declare that they have no conflict of interest.

Received: 25 June 2019 Accepted: 14 July 2019

Published online: 24 July 2019

References

1. Alcalay RN, Levy OA, Waters CC, Fahn S, Ford B, Kuo SH, Mazzoni P, Pauciulo MW, Nichols WC, Gan-Or Z et al (2015) Glucocerebrosidase activity in Parkinson's disease with and without GBA mutations. Brain 138:2648-2658. https://doi.org/10.1093/brain/awv179 
2. Al-Chalabi A, Durr A, Wood NW, Parkinson MH, Camuzat A, Hulot JS, Morrison KE, Renton A, Sussmuth SD, Landwehrmeyer BG et al (2009) Genetic variants of the alpha-synuclein gene SNCA are associated with multiple system atrophy. PLoS One 4:e7114. https://doi.org/10.1371/journal. pone.0007114

3. Allen M, Kachadoorian M, Quicksall Z, Zou F, Chai HS, Younkin C, Crook JE, Pankratz VS, Carrasquillo MM, Krishnan S et al (2014) Association of MAPT haplotypes with Alzheimer's disease risk and MAPT brain gene expression levels. Alzheimers Res Ther 6:39. https://doi.org/10.1186/alzrt268

4. Appel-Cresswell S, Vilarino-Guell C, Encarnacion M, Sherman H, Yu I, Shah B, Weir D, Thompson C, Szu-Tu C, Trinh J et al (2013) Alpha-synuclein p.H50Q, a novel pathogenic mutation for Parkinson's disease. Mov Disord 28:811813. https://doi.org/10.1002/mds.25421

5. Arima K, Ueda K, Sunohara N, Arakawa K, Hirai S, Nakamura M, TonozukaUehara H, Kawai M (1998) NACP/alpha-synuclein immunoreactivity in fibrillary components of neuronal and oligodendroglial cytoplasmic inclusions in the pontine nuclei in multiple system atrophy. Acta Neuropathol 96:439-444

6. Baker M, Litvan I, Houlden H, Adamson J, Dickson D, Perez-Tur J, Hardy J, Lynch T, Bigio E, Hutton M (1999) Association of an extended haplotype in the tau gene with progressive supranuclear palsy. Hum Mol Genet 8:711-715

7. Barca E, Kleiner G, Tang G, Ziosi M, Tadesse S, Masliah E, Louis ED, Faust P, Kang UJ, Torres Jet al (2016) Decreased coenzyme Q10 levels in multiple system atrophy cerebellum. J Neuropathol Exp Neurol 75: 663-672 https:// doi.org/10.1093/jnen/nlw037

8. Blandini F, Cilia R, Cerri S, Pezzoli G, Schapira AHV, Mullin S, Lanciego JL (2019) Glucocerebrosidase mutations and synucleinopathies: toward a model of precision medicine. Mov Disord 34:9-21. https://doi.org/10.1002/ mds.27583

9. Bodea LG, Eckert A, Ittner LM, Piguet O, Gotz J (2016) Tau physiology and pathomechanisms in frontotemporal lobar degeneration. J Neurochem 138(Suppl 1):71-94. https://doi.org/10.1111/jnc.13600

10. Bower JH, Maraganore DM, McDonnell SK, Rocca WA (1997) Incidence of progressive supranuclear palsy and multiple system atrophy in Olmsted County, Minnesota, 1976 to 1990. Neurology 49:1284-1288

11. Buee L, Bussiere T, Buee-Scherrer V, Delacourte A, Hof PR (2000) Tau protein isoforms, phosphorylation and role in neurodegenerative disorders. Brain Res Brain Res Rev 33:95-130

12. Cairns NJ, Atkinson PF, Hanger DP, Anderton BH, Daniel SE, Lantos PL (1997) Tau protein in the glial cytoplasmic inclusions of multiple system atrophy can be distinguished from abnormal tau in Alzheimer's disease. Neurosci Lett 230:49-52

13. Chen X, Chen Y, Wei Q, Ou R, Cao B, Zhao B, Shang HF (2016) C9ORF72 repeat expansions in Chinese patients with Parkinson's disease and multiple system atrophy. J Neural Transm (Vienna) 123:1341-1345. https://doi.org/1 0.1007/s00702-016-1598-2

14. Chen X, de Silva HA, Pettenati MJ, Rao PN, St George-Hyslop P, Roses AD, Xia Y, Horsburgh K, Ueda K, Saitoh T (1995) The human NACP/alphasynuclein gene: chromosome assignment to 4q21.3-q22 and Taql RFLP analysis. Genomics 26:425-427

15. Chen Y, Wei QQ, Ou R, Cao B, Chen X, Zhao B, Guo X, Yang Y, Chen K, Wu Y et al (2015) Genetic variants of SNCA are associated with susceptibility to Parkinson's disease but not amyotrophic lateral sclerosis or multiple system atrophy in a Chinese population. PLoS One 10:e0133776. https://doi.org/1 0.1371/journal.pone.0133776

16. Chen YP, Zhao B, Cao B, Song W, Guo X, Wei Q, Yang Y, Yuan LX, Shang H (2015) Mutation scanning of the COQ2 gene in ethnic Chinese patients with multiple-system atrophy. Neurobiol aging 361222 e1227-1222.e1211

17. Clayton DF, George JM (1998) The synucleins: a family of proteins involved in synaptic function, plasticity, neurodegeneration and disease. Trends Neurosci 21:249-254

18. Cruchaga C, Vidal-Taboada JM, Ezquerra M, Lorenzo E, Martinez-Lage P, Blazquez M, Tolosa E, Iberian Atypical Parkinsonism Study Group R, Pastor P (2009) 5'-upstream variants of CRHR1 and MAPT genes associated with age at onset in progressive supranuclear palsy and cortical basal degeneration. Neurobiol Dis 33:164-170. https://doi.org/10.1016/j.nbd.2008.09.027

19. Cuccaro D, De Marco EV, Cittadella R, Cavallaro S (2017) Copy number variants in Alzheimer's disease. J Alzheimers Dis 55:37-52. https://doi.org/1 $0.3233 / \mathrm{jad}-160469$

20. DeJesus-Hernandez M, Mackenzie IR, Boeve BF, Boxer AL, Baker M Rutherford NJ, Nicholson AM, Finch NA, Flynn H, Adamson J et al (2011)
Expanded GGGGCC hexanucleotide repeat in noncoding region of C9ORF72 causes chromosome 9p-linked FTD and ALS. Neuron 72:245-256. https://doi.org/10.1016/j.neuron.2011.09.011

21. Desbats MA, Morbidoni V, Silic-Benussi M, Doimo M, Ciminale V, Cassina M, Sacconi S, Hirano M, Basso G, Pierrel F et al (2016) The COQ2 genotype predicts the severity of coenzyme Q10 deficiency. Hum Mol Genet 25:42564265. https://doi.org/10.1093/hmg/ddw257

22. Federoff M, Price TR, Sailer A, Scholz S, Hernandez D, Nicolas A, Singleton AB, Nalls M, Houlden H (2016) Genome-wide estimate of the heritability of multiple system atrophy. Parkinsonism Relat Disord 22:35-41. https://doi. org/10.1016/j.parkreldis.2015.11.005

23. Federoff M, Schottlaender LV, Houlden H, Singleton A (2015) Multiple system atrophy: the application of genetics in understanding etiology. Clin Auton Res 25:19-36. https://doi.org/10.1007/s10286-014-0267-5

24. Ferguson MC, Garland EM, Hedges L, Womack-Nunley B, Hamid R, Phillips JA 3rd, Shibao CA, Raj SR, Biaggioni I, Robertson D (2014) SHC2 gene copy number in multiple system atrophy (MSA). Clin Auton Res 24:25-30. https:// doi.org/10.1007/s10286-013-0216-8

25. Fogel BL, Clark MC, Geschwind DH (2014) The neurogenetics of atypical parkinsonian disorders. Semin Neurol 34:217-224. https://doi.org/10.1055/s0034-1381738

26. Gai WP, Power JH, Blumbergs PC, Blessing WW (1998) Multiple-system atrophy: a new alpha-synuclein disease? Lancet 352:547-548

27. Gu X, Chen Y, Zhou Q, Lu YC, Cao B, Zhang L, Kuo MC, Wu YR, Wu RM, Tan EK et al (2018) Analysis of GWAS-linked variants in multiple system atrophy. Neurobiol Aging: Doi. https://doi.org/10.1016/j.neurobiolaging.2018.03.018

28. Halliday GM, Stevens CH (2011) Glia: initiators and progressors of pathology in Parkinson's disease. Mov Disord 26:6-17. https://doi.org/10.1002/ mds. 23455

29. Hama Y, Katsu M, Takigawa I, Yabe I, Matsushima M, Takahashi I, Katayama T, Utsumi J, Sasaki H (2017) Genomic copy number variation analysis in multiple system atrophy. Mol Brain 10:54. https://doi.org/10.1186/s13041-017-0335-6

30. Hasegawa T, Baba T, Kobayashi M, Konno M, Sugeno N, Kikuchi A, Itoyama Y, Takeda A (2010) Role of TPPP/p25 on alpha-synuclein-mediated oligodendroglial degeneration and the protective effect of SIRT2 inhibition in a cellular model of multiple system atrophy. Neurochem Int 57:857-866. https://doi.org/10.1016/j.neuint.2010.09.002

31. Heckman MG, Schottlaender L, Soto-Ortolaza Al, Diehl NN, Rayaprolu S, Ogaki K, Fujioka S, Murray ME, Cheshire WP, Uitti RJ et al (2014) LRRK2 exonic variants and risk of multiple system atrophy. Neurology 83:22562261. https://doi.org/10.1212/WNL.0000000000001078

32. Hernandez D, Paisan Ruiz C, Crawley A, Malkani R, Werner J, Gwinn-Hardy K, Dickson D, Wavrant Devrieze F, Hardy J, Singleton A (2005) The dardarin G 2019 S mutation is a common cause of Parkinson's disease but not other neurodegenerative diseases. Neurosci Lett 389:137-139. https://doi.org/10.1 016/j.neulet.2005.07.044

33. Islam MS, Moore DJ (2017) Mechanisms of LRRK2-dependent neurodegeneration: role of enzymatic activity and protein aggregation. Biochem Soc Trans 45:163-172. https://doi.org/10.1042/BST20160264

34. Jellinger KA, Wenning GK (2016) Multiple system atrophy: pathogenic mechanisms and biomarkers. J Neural Transm (Vienna) 123:555-572. https:// doi.org/10.1007/s00702-016-1545-2

35. Jeon BS, Farrer MJ, Bortnick SF, Korean Canadian Alliance on Parkinson's D, Related D (2014) Mutant COQ2 in multiple-system atrophy. N Engl J Med 371:80. https://doi.org/10.1056/NEJMc1311763\#SA1

36. Kadavath H, Hofele RV, Biernat J, Kumar S, Tepper K, Urlaub H, Mandelkow E, Zweckstetter M (2015) Tau stabilizes microtubules by binding at the interface between tubulin heterodimers. Proc Natl Acad Sci U S A 112: 7501-7506. https://doi.org/10.1073/pnas.1504081112

37. Kato S, Nakamura H (1990) Cytoplasmic argyrophilic inclusions in neurons of pontine nuclei in patients with olivopontocerebellar atrophy: immunohistochemical and ultrastructural studies. Acta Neuropathol 79:584-594

38. Kiely AP, Asi YT, Kara E, Limousin P, Ling H, Lewis P, Proukakis C, Quinn N, Lees AJ, Hardy Jet al (2013) Alpha-Synucleinopathy associated with G51D SNCA mutation: a link between Parkinson's disease and multiple system atrophy? Acta Neuropathol 125: 753-769 https://doi.org/10.1007/s00401-013-1096-7

39. Kiely AP, Ling H, Asi YT, Kara E, Proukakis C, Schapira AH, Morris HR, Roberts HC, Lubbe S, Limousin Pet al (2015) Distinct clinical and neuropathological features of G51D SNCA mutation cases compared with SNCA duplication and H50Q mutation. Mol Neurodegener 10: 41 https://doi.org/10.1186/s13 024-015-0038-3 
40. Kim HJ, Jeon BS, Lee JY, Yun JY (2011) Survival of Korean patients with multiple system atrophy. Mov Disord 26:909-912. https://doi.org/10.1002/ mds.23580

41. Kollensperger M, Geser F, Ndayisaba JP, Boesch S, Seppi K, Ostergaard K, Dupont E, Cardozo A, Tolosa E, Abele M et al (2010) Presentation, diagnosis, and management of multiple system atrophy in Europe: final analysis of the European multiple system atrophy registry. Mov Disord 25:2604-2612. https://doi.org/10.1002/mds.23192

42. Kruger R, Kuhn W, Muller T, Woitalla D, Graeber M, Kosel S, Przuntek H, Epplen JT, Schols L, Riess O (1998) Ala30Pro mutation in the gene encoding alpha-synuclein in Parkinson's disease. Nat Genet 18:106-108. https://doi. org/10.1038/ng0298-106

43. La Cognata V, Morello G, D'Agata V, Cavallaro S (2017) Copy number variability in Parkinson's disease: assembling the puzzle through a systems biology approach. Hum Genet 136:13-37. https://doi.org/10.1007/s00439016-1749-4

44. Labbe C, Heckman MG, Lorenzo-Betancor O, Murray ME, Ogaki K, SotoOrtolaza Al, Walton RL, Fujioka S, Koga S, Uitti RJ et al (2016) MAPT haplotype diversity in multiple system atrophy. Parkinsonism Relat Disord 30:40-45. https://doi.org/10.1016/j.parkreldis.2016.06.010

45. Lee JA, Lupski JR (2006) Genomic rearrangements and gene copy-number alterations as a cause of nervous system disorders. Neuron 52:103-121. https://doi.org/10.1016/j.neuron.2006.09.027

46. Mitsui J, Matsukawa T, Ishiura H, Y F, Ichikawa Y, H D (2013) Mutations in COQ2 in familial and sporadic multiple-system atrophy. N Engl J Med 369: 233-244 https://doi.org/10.1056/NEJMoa1212115

47. Mitsui J, Matsukawa T, Sasaki H, Yabe I, Matsushima M, Durr A, Brice A, Takashima H, Kikuchi A, Aoki M et al (2015) Variants associated with Gaucher disease in multiple system atrophy. Ann Clin Transl Neurol 2:417426. https://doi.org/10.1002/acn3.185

48. Mitsui J, Matsukawa T, Yasuda T, Ishiura H, Tsuji S (2016) Plasma coenzyme Q10 levels in patients with multiple system atrophy. JAMA Neurol 73:977_ 980. https://doi.org/10.1001/jamaneurol.2016.1325

49. Mongelli A, Sarro L, Rizzo E, Nanetti L, Meucci N, Pezzoli G, Goldwurm S, Taron F, Mariotti C, Gellera C (2018) Multiple system atrophy and CAG repeat length: a genetic screening of polyglutamine disease genes in Italian patients. Neurosci Lett 678:37-42. https://doi.org/10.1016/j.neulet.2018.04.044

50. Nakazato Y, Yamazaki H, Hirato J, Ishida Y, Yamaguchi H (1990) Oligodendroglial microtubular tangles in olivopontocerebellar atrophy. J Neuropathol Exp Neurol 49:521-530

51. Nicoletti G, Gagliardi M, Procopio R, lannello G, Morelli M, Annesi G, Quattrone A (2018) A new CHCHD2 mutation identified in a southern Italy patient with multiple system atrophy. Parkinsonism Relat Disord 47:91-93. https://doi.org/10.1016/j.parkreldis.2017.12.005

52. Ota K, Obayashi M, Ozaki K, Ichinose S, Kakita A, Tada M, Takahashi H, Ando N, Eishi Y, Mizusawa H et al (2014) Relocation of p25alpha/tubulin polymerization promoting protein from the nucleus to the perinuclear cytoplasm in the oligodendroglia of sporadic and COQ2 mutant multiple system atrophy. Acta Neuropathol Commun 2:136. https://doi.org/10.1186/ s40478-014-0136-4

53. Ozawa T, Revesz T, Paviour D, Lees AJ, Quinn N, Tada M, Kakita A, Onodera O, Wakabayashi K, Takahashi $\mathrm{H}$ et al (2012) Difference in MSA phenotype distribution between populations: genetics or environment? J Park Dis 2:718. https://doi.org/10.3233/jpd-2012-11056

54. Ozelius LJ, Foroud T, May S, Senthil G, Sandroni P, Low PA, Reich S, Colcher A, Stern MB, Ondo WG et al (2007) G2019S mutation in the leucine-rich repeat kinase 2 gene is not associated with multiple system atrophy. Mov Disord 22:546-549. https://doi.org/10.1002/mds.21343

55. Paisan Ruiz C, Lewis P, Singleton A (2013) LRRK2: cause, risk, and mechanism. J Park Dis 3:85-103

56. Papapetropoulos S, Tuchman A, Laufer D, Papatsoris AG, Papapetropoulos N, Mash DC (2007) Causes of death in multiple system atrophy. J Neurol Neurosurg Psychiatry 78:327-329

57. Papp Ml, Kahn JE, Lantos PL (1989) Glial cytoplasmic inclusions in the CNS of patients with multiple system atrophy (striatonigral degeneration, olivopontocerebellar atrophy and shy-Drager syndrome). J Neurol Sci 94:79-100

58. Pasanen P, Myllykangas L, Siitonen M, Raunio A, Kaakkola S, Lyytinen J, Tienari PJ, Poyhonen M, Paetau A (2014) Novel alpha-synuclein mutation A53E associated with atypical multiple system atrophy and Parkinson's disease-type pathology. Neurobiol Aging 35(2180):e2181-e2185. https://doi. org/10.1016/j.neurobiolaging.2014.03.024
59. Perez RG, Waymire JC, Lin E, Liu JJ, Guo F, Zigmond MJ (2002) A role for alpha-synuclein in the regulation of dopamine biosynthesis. J Neurosci 22 3090-3099. 20026307

60. Pihlstrom L, Schottlaender L, Chelban V, MSAE C, Meissner WG, Federoff M, Singleton A, Houlden H (2018) Lysosomal storage disorder gene variants in multiple system atrophy. Brain 141:e53. https://doi.org/10.1093/brain/awy124

61. Polymeropoulos MH, Lavedan C, Leroy E, Ide SE, Dehejia A, Dutra A, Pike B, Root H, Rubenstein J, Boyer R et al (1997) Mutation in the alpha-synuclein gene identified in families with Parkinson's disease. Science 276:2045-2047

62. Quinzii CM, Lopez LC, Gilkerson RW, Dorado B, Coku J, Naini AB, LagierTourenne C, Schuelke M, Salviati L, Carrozzo R et al (2010) Reactive oxygen species, oxidative stress, and cell death correlate with level of CoQ10 deficiency. FASEB J 24:3733-3743. https://doi.org/10.1096/fj.09-152728

63. Renton AE, Majounie E, Waite A, Simon-Sanchez J, Rollinson S, Gibbs JR, Schymick JC, Laaksovirta H, van Swieten JC, Myllykangas L et al (2011) A hexanucleotide repeat expansion in C9ORF72 is the cause of chromosome 9p21linked ALS-FTD. Neuron 72:257-268. https:/doi.org/10.1016/j.neuron.2011.09.010

64. Riboldi GM, Palma JA, Cortes E, lida MA, Sikder T, Henderson B, Raj T, Walker $\mathrm{RH}$, Crary JF, Kaufmann $\mathrm{H}$ et al (2019) Early-onset pathologically proven multiple system atrophy with LRRK2 G2019S mutation. Mov Disord: Doi. https://doi.org/10.1002/mds.27710

65. Sailer A, Scholz SW, Nalls MA, Schulte C, Federoff M, Price TR, Lees A, Ross OA, Dickson DW, Mok K et al (2016) A genome-wide association study in multiple system atrophy. Neurology 87:1591-1598. https://doi.org/10.1212/ WNL.0000000000003221

66. Sasaki H, Emi M, lijima H, Ito N, Sato H, Yabe I, Kato T, Utsumi J, Matsubara K (2011) Copy number loss of (src homology 2 domain containing)transforming protein 2 (SHC2) gene: discordant loss in monozygotic twins and frequent loss in patients with multiple system atrophy. Mol Brain 4:24 https://doi.org/10.1186/1756-6606-4-24

67. Scholz SW, Houlden H, Schulte C, Sharma M, Li A, Berg D, Melchers A, Paudel R, Gibbs JR, Simon-Sanchez J et al (2009) SNCA variants are associated with increased risk for multiple system atrophy. Ann Neurol 65: 610-614. https://doi.org/10.1002/ana.21685

68. Scholz SW, Majounie E, Revesz T, Holton JL, Okun MS, Houlden H, Singleton AB (2015) Multiple system atrophy is not caused by C9orf72 hexanucleotide repeat expansions. Neurobiol Aging 36(1223):e1221-e1222. https://doi.org/1 0.1016/j.neurobiolaging.2014.08.033

69. Schottlaender LV, Polke JM, Ling H, MacDoanld ND, Tucci A, Nanji T, Pittman A, de Silva R, Holton JL, Revesz Tet al (2015) The analysis of C9orf72 repeat expansions in a large series of clinically and pathologically diagnosed cases with atypical parkinsonism(). Neurobiol Aging 36: 1221 e1221-e1226

70. Schrag A, Ben-Shlomo Y, Quinn N (1999) Prevalence of progressive supranuclear palsy and multiple system atrophy: a cross-sectional study. Lancet 354:1771-1775

71. Schrag A, Wenning GK, Quinn N, Ben-Shlomo Y (2008) Survival in multiple system atrophy. Mov Disord 23:294-296

72. Segarane B, Li A, Paudel R, Scholz S, Neumann J, Lees A, Revesz T, Hardy J Mathias CJ, Wood NWet al (2009) Glucocerebrosidase mutations in 108 neuropathologically confirmed cases of multiple system atrophy. Neurology 72: 1185-1186 https://doi.org/10.1212/01.wnl.0000345356.40399.eb

73. Sklerov M, Kang UJ, Liong C, Clark L, Marder K, Pauciulo M, Nichols WC, Chung WK, Honig LS, Cortes E et al (2017) Frequency of GBA variants in autopsy-proven multiple system atrophy. Movement Disorders Clinical Practice: n/a-n/a Doi. https://doi.org/10.1002/mdc3.12481

74. Stefanova N, Wenning GK (2016) Review: multiple system atrophy: emerging targets for interventional therapies. Neuropathol Appl Neurobiol 42:20-32. https://doi.org/10.1111/nan.12304

75. Sun QY, Guo JF, Han WW, Zuo X, Wang L, Yao LY, Pan Q, Xia K, Yan XX, Tang BS (2013) Genetic association study of glucocerebrosidase gene L444P mutation in essential tremor and multiple system atrophy in mainland China. J Clin Neurosci 20:217-219. https://doi.org/10.1016/j.jocn.2012.01.055

76. Sun Z, Jiang H, Jiao B, Hou X, Shen L, Xia K, Tang B (2015) C9orf72 hexanucleotide expansion analysis in Chinese patients with multiple system atrophy. Parkinsonism Relat Disord 21:811-812. https://doi.org/10.1016/j. parkreldis.2015.04.008

77. Sun Z, Ohta Y, Yamashita T, Sato K, Takemoto M, Hishikawa N, Abe K (2016) New susceptible variant of COQ2 gene in Japanese patients with sporadic multiple system atrophy. Neurol Genet 2:e54. https://doi.org/10.1212/NXG. 0000000000000054 
78. Toft M, Ross OA (2010) Copy number variation in Parkinson's disease. Genome Med 2:62. https://doi.org/10.1186/gm183

79. Ubhi K, Rockenstein E, Mante M, Inglis C, Adame A, Patrick C, Whitney K, Masliah $E$ (2010) Neurodegeneration in a transgenic mouse model of multiple system atrophy is associated with altered expression of oligodendroglial-derived neurotrophic factors. J Neurosci 30:6236-6246. https://doi.org/10.1523/JNEUROSCI.0567-10.2010

80. Vilarino-Guell C, Soto-Ortolaza Al, Rajput A, Mash DC, Papapetropoulos S, Pahwa R, Lyons KE, Uitti RJ, Wszolek ZK, Dickson DWet al (2011) MAPT H1 haplotype is a risk factor for essential tremor and multiple system atrophy. Neurology 76: 670-672 https://doi.org/10.1212/WNL.0b013e31820c30c1

81. Wakabayashi K, Yoshimoto M, Tsuji S, Takahashi H (1998) Alpha-synuclein immunoreactivity in glial cytoplasmic inclusions in multiple system atrophy. Neurosci Lett 249:180-182

82. Wang Y, Mandelkow E (2016) Tau in physiology and pathology. Nat Rev Neurosci 17:5-21. https://doi.org/10.1038/nrn.2015.1

83. Watanabe H, Saito Y, Terao S, Ando T, Kachi T, Mukai E, Aiba I, Abe Y, Tamakoshi A, Doyu M et al (2002) Progression and prognosis in multiple system atrophy: an analysis of 230 Japanese patients. Brain 125:1070-1083

84. Weingarten MD, Lockwood AH, Hwo SY, Kirschner MW (1975) A protein factor essential for microtubule assembly. Proc Natl Acad Sci U S A 72:1858-1862

85. Wen XD, Li HF, Wang HX, Ni W, Dong Y, Wu ZY (2015) Mutation analysis of COQ2 in Chinese patients with cerebellar subtype of multiple system atrophy. CNS Neurosci Ther 21:626-630. https://doi.org/10.1111/cns.12412

86. Whittaker HT, Qui Y, Bettencourt C, Houlden H (2017) Multiple system atrophy: genetic risks and alpha-synuclein mutations. F1000Res 62072. https://doi.org/10.12688/f1000research.12193.1

87. Yang X, An R, Zhao Q, Zheng J, Tian S, Chen Y, Xu Y (2016) Mutational analysis of CHCHD2 in Chinese patients with multiple system atrophy and amyotrophic lateral sclerosis. J Neurol Sci 368:389-391. https://doi.org/10.1016/j.jns.2016.07.063

88. Yazawa I, Giasson BI, Sasaki R, Zhang B, Joyce S, Uryu K, Trojanowski JQ, Lee VM (2005) Mouse model of multiple system atrophy alpha-synuclein expression in oligodendrocytes causes glial and neuronal degeneration. Neuron 45:847-859. https://doi.org/10.1016/j.neuron.2005.01.032

89. Yuan X, Chen Y, Cao B, Zhao B, Wei Q, Guo X, Yang Y, Yuan L, Shang H (2015) An association analysis of the R1628P and G2385R polymorphisms of the LRRK2 gene in multiple system atrophy in a Chinese population. Parkinsonism Relat Disord 21:147-149. https:/doi.org/10.1016/j.parkreldis.2014.11.022

90. Zabetian CP, Hutter CM, Factor SA, Nutt JG, Higgins DS, Griffith A, Roberts JW, Leis BC, Kay DM, Yearout D et al (2007) Association analysis of MAPT H1 haplotype and subhaplotypes in Parkinson's disease. Ann Neurol 62:137144. https://doi.org/10.1002/ana.21157

91. Zarranz JJ, Alegre J, Gomez-Esteban JC, Lezcano E, Ros R, Ampuero I, Vidal L, Hoenicka J, Rodriguez O, Atares B et al (2004) The new mutation, E46K, of alpha-synuclein causes Parkinson and Lewy body dementia. Ann Neurol 55: 164-173. https://doi.org/10.1002/ana.10795

92. Zhao F, Bi L, Wang W, Wu X, Li Y, Gong F, Lu S, Feng F, Qian Z, Hu C et al (2016) Mutations of glucocerebrosidase gene and susceptibility to Parkinson's disease: An updated meta-analysis in a European population. Neuroscience 320:239-246. https://doi.org/10.1016/..neuroscience.2016.02.007

93. Zhao Q, Yang X, Tian S, An R, Zheng J, Xu Y (2016) Association of the COQ2 V393A variant with risk of multiple system atrophy in east Asians: a casecontrol study and meta-analysis of the literature. Neurol Sci 37:423-430. https://doi.org/10.1007/s10072-015-2414-8

94. Zhou X, Wang C, Chen Z, Peng Y, Peng H, Hou X, Ye W, Qiu R, Xia K, Tang B et al (2017) Association of TNF-a rs1799964 and IL-1 $\beta$ rs16944 polymorphisms with multiple system atrophy in Chinese Han population. International journal of neuroscience: 1-4 https:/doi.org/10.1080/00207454.2017.1418346

95. Zhou X, Wang C, Ding D, Chen Z, Peng Y, Peng H, Hou X, Wang P, Hou X, Ye W et al (2018) Analysis of (CAG) $n$ expansion in ATXN1, ATXN2 and ATXN3 in Chinese patients with multiple system atrophy. Sci Rep 8:3889. https://doi.org/10.1038/s41598-018-22290-0

96. Zimprich A, Biskup S, Leitner P, Lichtner P, Farrer M, Lincoln S, Kachergus J, Hulihan M, Uitti RJ, Calne DBet al (2004) Mutations in LRRK2 cause autosomal-dominant parkinsonism with pleomorphic pathology. Neuron 44: 601-607 https://doi.org/10.1016/j.neuron.2004.11.005

\section{Publisher's Note}

Springer Nature remains neutral with regard to jurisdictional claims in published maps and institutional affiliations.

Ready to submit your research? Choose BMC and benefit from:

- fast, convenient online submission

- thorough peer review by experienced researchers in your field

- rapid publication on acceptance

- support for research data, including large and complex data types

- gold Open Access which fosters wider collaboration and increased citations

- maximum visibility for your research: over $100 \mathrm{M}$ website views per year

At $\mathrm{BMC}$, research is always in progress.

Learn more biomedcentral.com/submissions 